\title{
Pengaruh Current Ratio Dan Debt To Equity Ratio Terhadap Return On Asset Pada PT. Gudang Garam, Tbk
}

\author{
Ilham 1) \\ 1) dosen Sekolah Tinggi IImu Ekonomi YPN Karawang, email : ilham.balanipa@gmail.com
}

ARTICLES
INFORMATION

\section{JURNAL SEKURITAS \\ (Saham, Ekonomi, Keuangan dan Investasi ) \\ Vol.3, No.3, Mei 2020 \\ Halaman : $289-299$ \\ @ LPPM \& Prodi Manajemen UNVERSITAS PAMULANG}

\section{ISSN (online) : 2581-2777 \\ ISSN (print) : : 2581-2696}

\section{Keyword : \\ Current Ratio; Debt to Equity Ratio; Return on Asset}

\section{JEL. classification :}

Q15

\section{Contact Author : \\ PRODI MANAJEMEN UNPAM \\ JL.Surya Kencana No.1 \\ Pamulang Tangerang Selatan - Banten \\ Telp. (021) 7412566, Fax (021) 7412491 \\ Email : \\ sekuritas@unpam.ac.id}

Untuk mendapatkan informasi tentang pengaruh Current Ratio dan Debt to Equity Ratio terhadap Return on Asset pada PT. Gudang Garam, Tbk menjadi tujuan dari penelitian ini. Melalui metode explanatory research dan statistik analisis dengan pengujian regresi linier berganda. Hasil penelitian menunjukkan Current Ratio mempengaruhi Return on Asset secara positif dan signifikan sebesar 39,1\%). Debt to Equity Ratio mempengaruhi Return on Asset secara negatif dan tidak signifikan sebesar $39,3 \%$, sedangkan secara simultan Current Ratio dan Debt to Equity Ratio mempengaruhi Return on asset secara positif dan signifikan sebesar $44,0 \%$.

This study aims to determine the effect of Current Ratio and Debt to Equity Ratio on Return on Assets at PT. Gudang Garam, Tbk. The method used is explanatory research. The analysis technique uses linier regression testing. The results of this study Current Ratio have a positive and significant effect on Return on Assets of 39.1\%, Debt to Equity Ratio has a negative but not significant effect on Return on Assets of $39.3 \%$. Current Ratio and Debt to Equity Ratio simultaneously have a positive and significant effect on Return on Assets of $44.0 \%$. 


\section{A. PENDAHULUAN}

Peranan industri rokok di Tanah air saat ini terlihat semakin besar, ini dapat di lihat dari semakin besarnya penerimaan negara dari cukai dan juga pajak rokok dari tahun ke tahun. Industri rokok juga menjadi motor penggerak ekonomi dengan tingkat volume industri yang sangat besar dan dalam industri ini juga dapat menyerap tenaga dalam jumlah yang sangat besar.

Meningkatnya penjualan rokok tidak lepas dari semakin banyaknya jumlah perokok di indonesia, pasar rokok dalam negeri akan terus berkembang dimana perkembangannya dipicu oleh adanya konsumen baru khususnya di kalangan remaja dan anak muda yang menginginkan rokok sebagai teman yang dapat mewakili bagian dari dirinya di pergaulan sosialnya.

Current ratio atau ratio lancar diperoleh dari perbandingan antara aktiva dengan hutang lancar (Pribadi, 2012:256). Apabila persentase ratio lancar dalam sebuah perusahaan rendah, maka dianggap terjadinya masalah dalam likuidasi. Dengan kata lain, perusahaan tidak memiliki kemampuan dan kesempatan untuk memenuhi kewajiban jangka pendeknya. Sebaliknya, jika rasio lancar dalam perusahaan tinggi maka dapat dikatakan baik bagi perusahaan tersebut.

\section{Tabel 1. Perkembangan Current Ratio dan Debt To Equity Ratio PT. Gudang Garam Tbk Periode 2010 - 2018}

\begin{tabular}{|c|c|c|c|c|c|c|}
\hline \multirow{2}{*}{ Tahun } & \multicolumn{2}{|c|}{ Current ratio } & \multirow{2}{*}{ Rasio\% } & \multicolumn{2}{|c|}{ Debt To Equity Ratio } & \multirow{2}{*}{ Rasio\% } \\
\cline { 2 - 3 } & $\begin{array}{c}\text { Aktiva } \\
\text { lancar }\end{array}$ & $\begin{array}{c}\text { Hutang } \\
\text { lancar }\end{array}$ & & $\begin{array}{c}\text { Total } \\
\text { Hutang }\end{array}$ & Ekuitas & \\
\hline 2010 & $19,584,533$ & $7,961,279$ & 246.00 & $8,848,424$ & $18,301,537$ & 48.35 \\
\hline 2011 & $22,908,293$ & $8,481,933$ & 270.08 & $9,421,403$ & $21,197,162$ & 44.45 \\
\hline 2012 & $30,381,754$ & $13,534,319$ & 224.48 & $14,537,777$ & $24,550,928$ & 59.21 \\
\hline 2013 & $28,389,468$ & $12,999,541$ & 218.39 & $14,035,485$ & $24,665,366$ & 56.90 \\
\hline 2014 & $34,604,461$ & $20,094,580$ & 172.21 & $21,353,980$ & $29,416,471$ & 72.59 \\
\hline 2015 & $38,352,600$ & $23,783,134$ & 161.26 & $24,991,880$ & $33,228,720$ & 75.21 \\
\hline 2016 & $38,354,710$ & $22,230,920$ & 172.53 & $23,578,714$ & $35,762,675$ & 65.93 \\
\hline 2017 & $41,933,173$ & $21,638,565$ & 193.79 & $23,387,406$ & $39,564,228$ & 59.11 \\
\hline 2018 & $66,759,930$ & $22,611,042$ & 295.25 & $24,572,266$ & $42,187,664$ & 58.25 \\
\hline
\end{tabular}

Berdasarkan tabel diatas dapat dijelaskan bahwa current ratio dari tahun 2010-2018 mengalami konsidi fluktuatif. Current ratio tertinggi mencapai persentase sebesar $295,25 \%$ pada tahun 2018 dan terendah mencapai persentase sebesar 161,26\% pada tahun 2014 . 
Kondisi serupa terlihat pada Debt To Equity Ratio dari tahun 2010-2018 mengalami kondisi yang fluktuatif pula. Debt to equity ratio tertinggi mencapai persentase sebesar $75,21 \%$ pada tahun 2015 dan terendah mencapai persentase sebesar $44,45 \%$ pada tahun 2011

Tabel 2. Perhitungan Return On Assets, PT. Gudang Garam Tbk Tahun 2010-2018

\begin{tabular}{|c|c|c|c|}
\hline \multirow{2}{*}{ Tahun } & \multicolumn{2}{|c|}{ Return On Asset } & \multirow{2}{*}{$\begin{array}{c}\text { Rasio } \\
\%\end{array}$} \\
\cline { 2 - 3 } & EAT & Total aktiva & 12.69 \\
\hline 2010 & $3,455,702$ & $27,230,965$ & 13.49 \\
\hline 2011 & $4,146,282$ & $30,741,679$ & 5.95 \\
\hline 2012 & $2,325,217$ & $39,088,705$ & 5.50 \\
\hline 2013 & $2,128,364$ & $38,700,851$ & 8.63 \\
\hline 2014 & $4,383,932$ & $50,770,251$ & 6.99 \\
\hline 2015 & $4,067,582$ & $58,220,600$ & 6.91 \\
\hline 2016 & $4,114,147$ & $59,541,389$ & 10.60 \\
\hline 2017 & $6,672,682$ & $62,951,634$ & 11.62 \\
\hline 2018 & $7,755,347$ & $66,759,930$ & \\
\hline
\end{tabular}

Berdasarkan tabel diatas dapat dijelaskan Return on Assets pada tahun 2010-2018 mengalami kondisi yang fluktuatif. Return on Assets tertinggi mencapai persentase sebasar 13,49\% pada tahun 2011 dan terendah mencapai persentase sebesar 5,50\% pada tahun 2013.

Dari penjelasan pada latar belkang masalah, sehingga penulis memutuskan judul penelitian ini adalah "Pengaruh Current Ratio (CR) dan Debt to Equity Ratio (DER), Terhadap Return On Assets (ROA) pada PT. Gudang Garam, Tbk periode 2010-2018"

\section{B. KAJIAN LITERATUR}

\section{Current Ratio}

adalah kemampuan perusahaan dalam membayar hutang lancar, yang dapat dilhat dari perbandingan antara jumlah aktiva lancar dengan hutang lancar .

Current Ratio $=\frac{\text { Aktiva lancar }}{\text { hutang lancar }} \times 100 \%$.

\section{Debt to Equity Ratio}

Kemampuan modal sendiri perusahan dalam memenuhi seluruh kewajibannya yang terlihat melalui perbandingan hutang-hutang terhadap ekuitas. Debt to Equity Ratio (DER) menurut Kasmir (2013:151) adalah ratio perbandingan hutang dengan ekuitas .

Debt to Equity $=\frac{\text { Total hutang }}{\text { ekuitas }} \times 100 \%$ 


\section{Return on Asset}

Return on Asset merupakan alat ukur dari rasio profitabilitas. Pendapat yang dikemukakan Sartono (2010:64) yang menyatakan bahwa: "Rasio profitabilitas merupakan kegiatan dari manajemen yang secara keseluruhan yang ditujukan oleh besar kecilnya tingkat keuntungan yang didapat dalam hubungannya dengan penjualan, asset, modal maupun investasi”.

Return on Assets $=\frac{\text { lBba bersih setelah pajak }}{\text { total aktiva }} \times 100 \%$

\section{METODOLOGI PENELITIAN}

\section{Populasi}

Populasi dalam penelitian ini laporan keuangan selama 9 tahun PT. Gudang Garam, Tbk

\section{Sampel}

Teknik pengambilan sampling dalam penelitian ini adalah samplel jenuh, dimana semua anggota populasi dijadikan sebagai sampel. Dengan demikian sampel dalam penelitian ini laporan keuangan selama 9 tahun.

\section{Jenis Penelitian}

Jenis penelitian yang dipakai adalah asosiatif, dimana tujuannya adalah untuk mengetahui mencari keterhubungan antar variabel

\section{Metode Analisis Data}

Dalam menganalisis data digunakan Regresi linier beganda

\section{HASIL DAN PEMBAHASAN}

\section{Analisis Deskriptif}

Pada pengujian ini digunakan untuk mengetahui besarnya persentase minimum dan maksimum, persentase rata-rata dan standar deviasi dari masing-masing variabel. Adapun hasilnya sebagai berikut:

Tabel 1. Hasil Analisis Descriptive Statistics

\section{Descriptive Statistics}

\begin{tabular}{lr|r|r|r|r} 
& N & Minimum & Maximum & Mean & Std. Deviation \\
\hline Current Ratio (X1) & 9 & 161.26 & 295.25 & 217.1100 & 46.72887 \\
\hline Debt To Equity Ratio (X2) & 9 & 44.45 & 75.21 & 60.0000 & 10.10341 \\
\hline
\end{tabular}




\begin{tabular}{l|r|r|r|r|r}
\hline Return On Asset (Y) & 9 & 5.50 & 13.49 & 9.1533 & 3.02255 \\
\hline Valid N (listwise) & 9 & & & & \\
\hline
\end{tabular}

Current Ratio diperoleh nilai minimum sebesar $161,26 \%$ dan nilai maximum $295,25 \%$ dengan rata-rata sebesar $217,11 \%$ dengan standar deviasi $46,728 \%$.

Debt to Equity Ratio diperoleh nilai minimum sebesar $44,45 \%$ dan nilai maximum $75,21 \%$ dengan rata-rata sebesar $60,00 \%$ dengan standar deviasi $10,103 \%$.

Return on Asset diperoleh varians minimum sebesar $5,5 \%$ dan nilai maximum $13,49 \%$ dengan rata-rata sebesar $9,15 \%$ dengan standar deviasi $3,022 \%$.

\section{Analisis Verifikatif.}

\section{a. Analisis Regresi Linier Berganda}

Tabel 2. Hasil Pengujian Regresi Liner Berganda

\section{Coefficients $^{\mathrm{a}}$}

$$
\text { Unstandardized Coefficients } \begin{gathered}
\text { Standardized } \\
\text { Coefficients }
\end{gathered}
$$

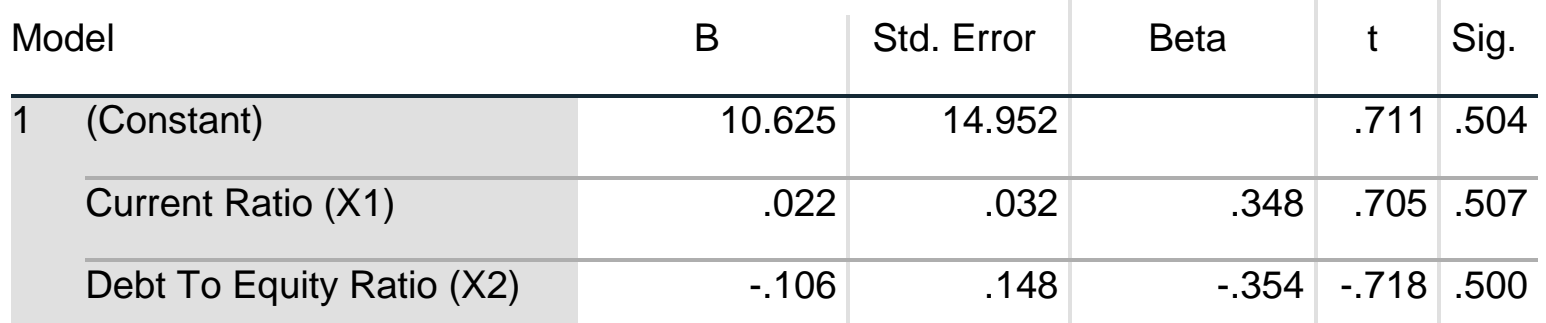

a. Dependent Variable: Return On Asset (Y)

Dari tabel diatas, didapat persamaan regresi $Y=10,625+0,022 X 1-0,106 X 2$. Dari persamaan tersebut dijelaskan :

1) 10,625 sebagai konstanta jika Current Ratio dan Debt to Equity Ratio tidak ada, maka nilai Return on Asset sebesar 10,625 point.

2) Koefisien regresi Current Ratio sebesar 0,022, angka ini positif artinya setiap ada peningkatan Current Ratio sebesar 0,022 maka Return on Asset akan meingkat sebesar 0,022 point.

3) Regresi Debt to Equity Ratio sebesar - 0,106, artinya setiap ada penutunan Debt to Equity Ratio sebesar - 0,106 Return on Asset juga akan menurun sebanyak 0,106 point. 


\section{b. Analisis Koefisien Korelasi}

Tabel 3. Hasil Pengujian Koefisien Korelasi Current Ratio Terhadap Return on Asset .

\section{Correlations $^{\mathrm{a}}$}

Current Ratio Return On Asset

(X1)

$(\mathrm{Y})$

\begin{tabular}{llr|r}
\hline Current Ratio (X1) & Pearson Correlation & 1 & .626 \\
\cline { 2 - 3 } & Sig. (2-tailed) & & .072 \\
\hline Return On Asset (Y) & Pearson Correlation & .626 & 1 \\
\cline { 2 - 3 } & Sig. (2-tailed) & .072 & \\
\hline
\end{tabular}

a. Listwise $\mathrm{N}=9$

Berdasarkan hasil uji dari tabel diatas, didapat nilai korelasi 0,626 dimana ini berarti Current Ratio berhubungan kuat dengan Return on Asset .

Tabel 4. Hasil Uji Koefisien Korelasi Debt to Equity Ratio Terhadap Return on Asset.

\section{Correlations $^{\mathrm{a}}$}

\begin{tabular}{ll|r|r} 
& & $\begin{array}{c}\text { Debt To Equity } \\
\text { Ratio (X2) }\end{array}$ & $\begin{array}{r}\text { Return On Asset } \\
(\mathrm{Y})\end{array}$ \\
\hline Debt To Equity Ratio (X2) & Pearson Correlation & 1 & -.627 \\
\cline { 2 - 4 } & Sig. (2-tailed) & & .071 \\
\hline Return On Asset (Y) & Pearson Correlation & -.627 & 1 \\
\hline & Sig. (2-tailed) & .071 & \\
\hline
\end{tabular}

a. Listwise $\mathrm{N}=9$

Berdasarkan hasil uji korelasi didapat - 0,627 artinya "Debt to Equity Ratio" memiliki hubungan yang negatif kuat terhadap Return on Asset .

Tabel 5. Hasil Uji Koefisien Korelasi Current Ratio dan Debt to Equity Ratio secara simultan Terhadap Return on Asset .

Model Summary

\begin{tabular}{lr|r|r|r} 
Model & $\mathrm{R}$ & R Square & Adjusted R Square & $\begin{array}{c}\text { Std. Error of the } \\
\text { Estimate }\end{array}$ \\
\hline 1 & $.663^{\mathrm{a}}$ & .440 & .253 & 2.61288
\end{tabular}

a. Predictors: (Constant), Debt To Equity Ratio (X2), Current Ratio (X1) 
Berdasarkan hasil uji pada tabel diatas, nilai korelasi 0,663 yang berarti secara simultan Current Ratio dan Debt to Equity Ratio berhubungan kuat terhadap Return on Asset.

\section{c. Analisis Koefisien Determinasi}

Analisis koefisien determinasi dimaksudkan untuk mengetahui besarnya persentase pengaruh dari variabel independen terhadap variabel dependen baik secara parsial maupun simultan.

Tabel 6. Hasil Uji Koefisien Determinasi Current Ratio Terhadap Return on Asset .

\section{Model Summary}

\begin{tabular}{l|l|l|l|l} 
Model & $R$ & R Square & Adjusted R Square & Std. Error of the Estimate
\end{tabular}

\begin{tabular}{lllll}
\hline 1 & $.626^{\mathrm{a}}$ & .391 & .305 & 2.52070 \\
\hline
\end{tabular}

a. Predictors: (Constant), Current Ratio (X1)

Berdasarkan hasil pengujian didapat determinasi 0,391 yang berarti Current Ratio memiliki kontribusi pengaruh sebesar 39,1\% terhadap Return on Asset.

Tabel 7. Hasil Uji Koefisien Determinasi Debt to Equity Ratio Terhadap Return on Asset .

\section{Model Summary}

\begin{tabular}{lr|r|r|r} 
Model & R & R Square & $\begin{array}{c}\text { Adjusted R } \\
\text { Square }\end{array}$ & \multicolumn{2}{|c}{$\begin{array}{c}\text { Std. Error of the } \\
\text { Estimate }\end{array}$} \\
\hline 1 & $.627^{\mathrm{a}}$ & .393 & .306 & 2.51717 \\
\hline
\end{tabular}

a. Predictors: (Constant), Debt To Equity Ratio (X2)

Berdasarkan hasil pengujian didapat determinasi sebesar 0,393 artinya Debt to Equity Ratio memiliki kontribusi pengaruh 39,3\% terhadap Return on Asset.

Tabel 8. Hasil Uji Koefisien Determinasi Current Ratio dan Debt to Equity Ratio Terhadap Return on Asset .

Model Summary

\begin{tabular}{l|r|r|r|r} 
Model & $\mathrm{R}$ & R Square & $\begin{array}{c}\text { Adjusted R } \\
\text { Square }\end{array}$ & Std. Error of the Estimate \\
\hline 1 & $.663^{\mathrm{a}}$ & .440 & .253 & 2.61288 \\
\hline
\end{tabular}

a. Predictors: (Constant), Debt To Equity Ratio (X2), Current Ratio (X1)

Berdasarkan hasil uji diatas didapat determinasi 0,440 ini berarti Current Ratio dan Debt to Equity Ratio secara simultan memiliki kontribusi pengaruh sebesar $44,0 \%$ terhadap Return on Asset, sedangkan $56,0 \%$ sisanya dipengaruhi oleh faktor yang lain. 


\section{d. Uji Hipotesis}

\section{Uji hipotesis Parsial (Uji t)}

Pengujian hipotesis dengan uji t digunakan untuk mengetahui hipotesis parsial mana yang diterima.

Tabel 9. Hasil Uji Hipotesis Current Ratio Terhadap Return on Asset.

\section{Coefficients $^{\mathrm{a}}$}

\begin{tabular}{|c|c|c|c|c|c|}
\hline \multirow[b]{2}{*}{ Model } & \multicolumn{2}{|c|}{ Unstandardized Coefficients } & \multirow{2}{*}{$\begin{array}{c}\text { Standardized } \\
\text { Coefficients } \\
\text { Beta }\end{array}$} & \multirow[b]{2}{*}{$\mathrm{t}$} & \multirow[b]{2}{*}{ Sig. } \\
\hline & $\mathrm{B}$ & Std. Error & & & \\
\hline $\begin{array}{ll}1 \text { (Constant) } \\
\end{array}$ & .367 & 4.225 & & .087 & .933 \\
\hline Current Ratio (X1) & .040 & .019 & .626 & 3.122 & .042 \\
\hline
\end{tabular}

a. Dependent Variable: Return On Asset (Y)

Dari hasil uji dari tabel di atas, didapat nilai $t$ hitung $>\mathrm{t}$ tabel atau $(3,122>2,365)$, dapat disimpulkan bahwa terdapat pengaruh yang signifikan atara Current Ratio terhadap Return on Asset.

Tabel 10. Hasil Uji Hipotesis Debt to Equity Ratio Terhadap Return on Asset.

\section{Coefficients $^{\mathrm{a}}$}

$$
\begin{array}{l|c}
\text { Unstandardized Coefficients } & \begin{array}{c}
\text { Standardized } \\
\text { Coefficients }
\end{array}
\end{array}
$$

\begin{tabular}{ll|r|r|r|r}
\multicolumn{1}{l|}{ Model } & B & Std. Error & Beta & \multicolumn{1}{c}{$\mathrm{t}$} & \multicolumn{1}{c}{ Sig. } \\
\hline 1 & 20.408 & 5.351 & & 3.814 & .007 \\
\hline $\begin{array}{l}\text { (Constant) } \\
\begin{array}{l}\text { Debt To Equity Ratic } \\
\text { (X2) }\end{array}\end{array}$ & -.188 & .088 & -.627 & -2.130 & .071 \\
\hline
\end{tabular}

a. Dependent Variable: Return On Asset (Y)

Dari hasil uji dari tabel di atas, didapat nilai t hitung $<\mathrm{t}$ tabel atau $(-2,130<2,365)$, dapat disimpulkan bahwa terdapat pengaruh yang negatif namun tidak signifikan antara Debt to Equity Ratio terhadap Return on Asset.

\section{Uji Hipotesis Simultan (Uji F)}

Pengujian hipotesis dengan uji $\mathrm{F}$ digunakan untuk mengetahui hipotesis simultan yang mana yang diterima.

Tabel 11. Hasil Uji Hipotesis Current Ratio dan Debt to Equity Ratio Terhadap Return on Asset. 


\section{ANOVA $^{\mathrm{a}}$}

\begin{tabular}{l|r|r|r|r|r} 
Model & Sum of Squares & df & Mean Square & F & Sig. \\
\hline 1 & 32.124 & 2 & 16.062 & 9.353 & $.045^{\mathrm{b}}$ \\
\hline $\begin{array}{l}\text { Regression } \\
\text { Residual }\end{array}$ & 40.963 & 6 & 6.827 & & \\
\hline Total & 73.087 & 8 & & & \\
\hline
\end{tabular}

a. Dependent Variable: Return On Asset (Y)

b. Predictors: (Constant), Debt To Equity Ratio (X2), Current Ratio (X1)

Dari hasil uji di atas, didapat nilai $F$ hitung $>F$ tabel atau $(9,353>4,350)$, sehingga dapat disimpulkan secara simultan Current Ratio dan Debt to Equity berpengaruh secara signifikan terhadap Return on Asset.

\section{E. PEMBAHASAN HASIL PENELITIAN}

\section{Pengaruh Current Ratio Terhadap Return on Asset}

Current Ratio berpengaruh signifikan terhadap Return on Asset, dengan hubungan 0,626 atau berhubungan kuat dengan kontribusi pengaruh sebesar $39,1 \%$. hasil uji hipotesis nilai $t$ hitung $>t$ tabel atau $(3,122>2,365)$. sehingga disimpulkan terdapat pengaruh signifikan antara Current Ratio terhadap Return on Asset.

\section{Pengaruh Debt to Equity Ratio Terhadap Return on Asset}

Debt to Equity Ratio mempengauhi Return on Asset secara sifnfikan, korelasi - 0,627 atau berhubungan negatif kuat dengan kontribusi pengaruh sebesar $39,3 \%$. Hasl uji hipotesis diperoleh nilai $t$ hitung $<\mathrm{t}$ tabel atau $(-2,130<2,365)$. Dengan demikian terdapat pengaruh negatif namun tidak signifikan antara Debt to Equity Ratio terhadap Return on Asset.

\section{Pengaruh Current Ratio dan Debt to Equity Ratio Terhadap Return on Asset}

Current Ratio dan Debt to Equity Ratio secara simultan mempengaruhi Return on Asset dengan sifnifikan dan persamaan regresi $Y=10,625+0,022 X 1+-0,106 X 2$, korelasi kuat sebesar 0,663 dan kontribusi pengaruh $44,0 \%$. Uji hipotesis didapat nilai $\mathrm{F}$ hitung $>\mathrm{F}$ tabel atau $(9,353>4,350)$.

\section{F. KESIMPULAN}

\section{Kesimpulan}

1. Current Ratio mempenaruhi Return on Asset secar signifikan, kontribusi pengaruh $39,1 \%$. Uji hipotesis didapat nilai $t$ hitung $>t$ tabel atau $(3,122>2,365)$.

2. Debt to Equity Ratio mempengaruhi Return on Asset secara signifikan, kontribusi pengaruh $39,3 \%$. Uji hipotesis didapat nilai t hitung $<\mathrm{t}$ tabel atau $(-2,130<2,365)$.

3. Current Ratio dan Debt to Equity Ratio mempengaruhin Return on Asset secra 
signifikan dengan pengaruh $44,0 \%$ sedangkan $56,0 \%$ sisnya dipengaruhi faktor lain. Uji hipotesis didapat nilai $F$ hitung $>F$ tabel atau $(9,353>4,350)$.

\section{Saran}

a. Untuk meningkatkan prosentase keuntungan perusahaan dapat dilakukan melalui peningkatan aktiva lancar guna meningkatkan jumlah uang yang diperoleh

b. Perusahaan disarankan untuk mempercepat kewajiban lancarnya dengan memperhitungkan siklus perputaran uang yang digunakan sehingga akan mampu menambah struktur modal dengan baik.

c. Disarankan kepada penelitian selanjutnya untuk melakukan penelitian terhadap variabel - variabel lainnya.

\section{DAFTAR PUSTAKA}

Algifari. (2015). “Analisis Regresi untuk Bisnis dan Ekonomi”. Yogyakarta: BPFE.

Arikunto, Suharsimi (2014). "Prosedur Penelitian Suatu Pendekatan Praktek". Jakarta: Rineka Cipta.

Bambang Riyanto, "Dasar-Dasar Pembelanjaan Perusahaan", Edisi keempat, Cetakan Kedelapan, Penerbit BPFE, Yogyakarta, 2009.

Brigham, Eugene F and Joel F.Houston, "Dasar-Dasar Manajemen Keuangan", alih bahasa Ali Akbar Yulianto, Buku satu, Edisi sepuluh, PT. Salemba Empat, Jakarta, 2006.

Harjito dan Martono, “Manajemen Keuangan”, Ekonisia, Yogyakarta, 2005.

Imam Ghozali (2017). “Aplikasi Analisis Multivariate Dengan Program SPSS”. Edisi Kelima. Semarang: Badan Penerbit Undip.

Istijanto (2014) “Riset Sumber Daya Manusia”. Jakarta: PT. Gramedia Pustaka

Jasmani, J. (2018). Pengaruh Kinerja Keuangan Terhadap Harga Saham (Analisis Pada Perusahaan Property dan Real Estate Yang Go Public di Bursa Efek Indonesia. Jurnal Akuntansi Indonesia, 12(2).

Kadim, A., \& Sunardi, N. (2019, May). Eviews Analysis; Determinan Tourism, Restaurant and Hotel Company's Soundness and Performance. In Proceeding Interuniversity Forum for Strengthening Academic Competency (Vol. 1, No. 1, pp. 332-340).

Kasmir, "Pengantar Manajemen Keuangan", Edisi Pertama, Cetakan kedua, Penerbit Prenada Media, Jakarta, 2012.

Kharis, Ismu Fadli (2011). "Studi Mengenai Impulse Buying dalam Penjualan Online". Semarang : Skripsi Universitas Diponegoro 
Lutfi, A. M., \& Sunardi, N. (2019). Pengaruh Current Ratio (Cr), Return On Equity (Roe), Dan Sales Growth Terhadap Harga Saham Yang Berdampak Pada Kinerja Keuangan Perusahaan (Pada Perusahaan Manufaktur Sektor Makanan Dan Minuman Yang Terdaftar Di Bursa Efek Indonesia). Jurnal SEKURITAS (Saham, Ekonomi, Keuangan dan Investasi), 2(3), 83-100.

Martono dan Agus Harjito, “Manajemen Keuangan”, Penerbit Ekonisia, Yogyakarta, 2011.

Martono dan Agus Harjito, “Manajemen Keuangan”, Penerbit Ekonisia, Yogyakarta, 2010.

Munawir, "Analisa Laporan Keuangan", Cetakan keempat, Penerbit Liberty, Yogyakarta, 2009.

Santoso, Singgih (2015). "Menguasai Statistik Multivariat". Jakarta: PT Elex Media Komputindo.

Sugiyono (2017), "Metode Penelitian Administrasi : dilengkapi dengan Metode $R \& D$ ". Bandung: Alfabeta.

Sunardi, N. (2017). Determinan Kebijakan Utang Serta Implikasinya terhadap Kinerja Perusahaan (Perusahaan yang tergabung dalam indeks LQ. 45 yang terdaftar di Bursa Efek Indonesia Tahun 2011-2015). Jurnal Sekuritas, 1(1).

Sunardi, N. (2018). Analisis Du Pont System Dengan Time Series Approach (Tsa) Dan Cross Sectional Approach (Csa) Dalam Penilaian Kinerja Keuangan Perusahaan (Studi Pada Industri Konstruksi (BUMN) di Indonesia Yang Listing di BEI Tahun 2013-2017). Jurnal SEKURITAS (Saham, Ekonomi, Keuangan dan Investasi), 1(4).

Sunardi, N. (2018). Kinerja Perusahan Pendekatan Du Pont System Terhadap Harga Dan Return Saham (Perusahaan yang tergabung dalam Industri Real Estate dan Properti yang terdaftar di Bursa Efek Indonesia Tahun 2011-2017). JIMF (Jurnal IImiah Manajemen Forkamma), 1(3).

Sunarsi, D. (2019). "The Analysis of The Work Environmental and Organizational Cultural Impact on The Performance and Implication of The Work Satisfaction". Jurnal IImiah Ilmu Administrasi Publik, 9(2), 113-122.

Sunarsi, D., \& Kusjono, G. (2019). “Pengaruh Lingkungan Kerja Non Fisik, Konflik Dan Turn Over Intention Terhadap Produktivitas Kerja Karyawan Pada CV. Usaha Mandiri Jakarta Selatan". Jurnal Ekonomi Efektif, 1(3). 